\title{
Market Definition and the Analysis of Antitrust in Banking
}

\author{
Myron L. Kwast* \\ Martha Starr-McCluer* \\ John D. Wolken*
}

October 1997

*Division of Research and Statistics, Board of Governors of the Federal Reserve System, Washington, D.C. 20551. The views expressed are those of the authors and do not necessarily reflect those of the Board of Governors or its staff. The authors thank Dean Amel, Tim Hannan, Wayne Passmore, Robin Prager, and Steve Rhoades for comments on a earlier draft. Any errors are the responsibility of the authors. 


\title{
Market definition and the analysis of antitrust in banking
}

\author{
BY MYRON L. KWAST, MARTHA STARR-MCCLUER, and JOHN D. WOLKEN
}

\section{Introduction}

The U.S. banking industry is currently experiencing the most significant consolidation in its history. The years 1981-1995 have averaged some 434 mergers among healthy banks per year, and have cumulated a stunning 1.6 trillion (1995) dollars in acquired bank assets. ${ }^{1}$ Several of these mergers, and especially some in the 1990s, have been the largest in U.S. history -- including the mergers of BankAmerica and Security Pacific, Chase Manhattan and Chemical, and Wells Fargo and First Interstate. Passage of interstate banking and branching legislation at the national level, the Riegle-Neal Act of 1994, can be expected to further encourage these trends, since it will allow the development of a truly national banking structure.

While the on-going consolidation of the U.S. banking system is in many ways long overdue, it also raises a number of public policy concerns. One of these concerns is the potential impact of consolidation on the competitiveness of banking markets. Under the Bank Holding Company Act, the Bank Merger Act, and other statutes, the U.S.

Department of Justice and the federal bank regulatory agencies are charged with enforcing the antitrust laws in banking. Thus, over the years, each of these agencies has developed procedures for analyzing the potential competitive impact of a proposed merger.

Current procedures for examining the potential competitive effects of bank mergers, while varying somewhat across agencies, are based on three fundamental

${ }^{1}$ See Stephen A. Rhoades, Bank Mergers and Industrywide Structure, 1980-94 (Staff Study No. 169, Board of Governors of the Federal Reserve System, January 1996). The above figures exclude mergers of failed banks. Beginning in the mid-1980s, and continuing through 1992, over 1,300 bank failures also contributed significantly to the consolidation of U.S. banking. 
concepts. $^{2}$ In particular: the (1) "cluster" of bank products is the relevant product line for competition analysis; this cluster is normally viewed as being consumed in (2) geographically local banking markets; and (3) market structure is a key determinant of the degree of competition. The precise definition of the cluster is vague, but is meant to encompass the set of products and services that are purchased primarily from banks. Products and services for which markets are viewed as being national or regional in scope are virtually never considered to have competitive problems; the focus is almost entirely on "locally limited products." Thus, in practice, competition analysis is almost exclusively centered on products consumed by households and small businesses, since these are the agents that are normally viewed as being the most likely to be locally limited in their purchases of at least some financial services. ${ }^{3}$

The current approach has received widespread, and often strong, criticism from bankers, academics, policy makers, and other market participants. ${ }^{4}$ Some argue that the concept of a cluster of banking services, while perhaps relevant in the 1960s, is hopelessly outdated in the modern financial world where virtually any banking product is offered not only by depository institutions (including thrifts), but also by many (often specialized) nonbanking firms. At a minimum, this argument says, the cluster should be broken up into those individual products and services where banks have potential market power. Others go further and argue that changing technology has made the concept of the local market obsolete. Today, such critics say, households and small businesses can purchase virtually any financial service virtually anywhere in the country from either an insured

2 These basic concepts were first confirmed by the U.S. Supreme Court in 1963 (the Philadelphia National Bank decision), and reconfirmed by lower courts as recently as 1987.

3 It is important to note that in recent years the Department of Justice has emphasized small business lending, and other small business customer relationships, as the most relevant local product, while the Federal Reserve has continued to rely on the (more general) concept of the cluster.

4 A recent forum for the expression of such criticisms was a conference on bank antitrust issues sponsored by the Office of the Comptroller of the Currency in November 1995. 
depository or an uninsured nonbank institution. Electronic banking, it is said, will only accelerate this trend. These critics view existing competition as sufficient to allay any concerns regarding the competitive effects of a bank merger. In addition, some argue that even if existing competition may sometimes be inadequate, potential competition is sufficient to assuage any competitive concerns. Such observers maintain that barriers to entry in banking are low, and that recent legislation allowing fuller interstate banking and branching has reduced entry barriers even more.

This paper attempts to contribute to this debate by utilizing two data sources that are particularly well-suited to examining some of the key hypotheses. Indeed, both data sets were in part designed precisely to allow such an analysis. The paper uses the 1992 Survey of Consumer Finances (SCF) and the 1993 National Survey of Small Business Finances (NSSBF) to examine the extent to which households and small businesses (1) tend to focus their purchases of financial services at insured depository, as opposed to nondepository, institutions, (2) purchase their financial services locally, and (3) tend to cluster their purchases of financial services at a single "primary" financial institution. A strong effort is made to define variables comparably across surveys so that households and small businesses can be easily compared. Indeed, a unique contribution of this paper is its simultaneous consideration of the two classes of agents most often thought of as potentially subject to market power in banking. In addition, previous studies of these issues are somewhat dated, and thus provide little evidence to address the major contemporary criticisms.

The next section reviews the literature, and Section III briefly describes the two surveys used in this study. Section IV considers the extent to which households and small businesses use depository and nondepository institutions for their purchases of financial services. Section V looks at the extent to which such services are purchased in geographically local markets, the next section examines the issue of clustering, and section VII addresses some difficulties in interpreting our data. Overall, the results are supportive of the current methodology used to analyze the potential competitive effects of bank mergers. Key household asset services, such as checking accounts, and important small business asset and credit services appear to a substantial degree to be obtained, and 
preferred to be obtained, at local depository institutions. Section VIII concludes and suggests some directions for future research.

\section{Literature Review}

Recent empirical evidence on the relevancy of the current approach to competitive analysis for bank mergers is limited, and increasingly dated. Elliehausen and Wolken ${ }^{5}$ analyzed data from the 1987 National Survey of Small Business Finances. ${ }^{6}{ }^{7}$ At that time, local commercial banks were the most widely used source for virtually every financial service used by small businesses. The study found a significant portion of small businesses obtaining services from nonbank institutions, but generally these sources were used for single products. Multiple service use was most often associated with the firm's primary institution, which was almost always a local commercial bank.

${ }^{5}$ Gregory E. Elliehausen and John D. Wolken, Banking Markets and the Use of Financial Services by Small and Medium-Sized Businesses, 76 FEDERAL Reserve BuLLETIN (October 1990).

${ }^{6}$ Following the Supreme Court's 1963 Philadelphia National Bank decision, a number of case studies of individual geographic areas (e.g., Nassau county, St. Louis) surveyed households and sometimes businesses to determine where and from what types of institutions these groups of bank customers obtained their financial services. Most of these studies were conducted in the late 1960s and throughout the 1970s. Generally these studies provided data confirming the dependence on local commercial banks in the geographic areas surveyed. See john D. Wolken, Geographic Market Delineation: a Review of the Literature (Staff Study, No. 140, Board of Governors of the Federal Reserve System, October 1984) for a detailed review of these studies.

${ }^{7}$ For a recent study examining banking markets for "middle market firms," see Robert Tannanwald, The Geographic Boundaries of New England's Middle-Lending Markets, Federal Reserve Bank of Boston, 15 New England EConomic ReVIEW (July-August 1994). 
Using the same data set, Elliehausen and Wolken explored the issue of clustering for small businesses. ${ }^{8}$ This study found that a large segment of the small business population clustered purchases of some financial services (particularly checking, lines of credit and some other services such as credit card receipt processing and cash management services). However, the results suggested that it was unlikely that the entire set of products offered by commercial banks belonged to "the cluster." Rather, some products likely belonged to separate markets.

The most recent study of household banking markets was conducted using data from the 1989 Survey of Consumer Finances. Elliehausen and Wolken found that local depository institutions, especially local commercial banks, were the main suppliers for most of the financial services used by households. ${ }^{9}$ Credit products were predominantly local, but not as local as checking and savings accounts. Nondepository institutions were generally local as well, but to a lesser extent than depository institutions. Multiple service usage was most often associated with the checking account, and the institution at which clustering occurred was almost always a local depository institution. The typical service bundle consisted of a checking account and another savings account or credit service. As was true for small businesses, some credit products, such as mortgages and vehicle loans, were often purchased separately.

III. The Surveys of Consumer and Small Business Finances

Both the 1992 SCF and the 1993 NSSBF were sponsored by the Federal Reserve Board. ${ }^{10}$ The 1992 SCF interviewed 3,906 households, asking detailed questions about

${ }^{8}$ Gregory E. Elliehausen and John D. Wolken, Small Business Clustering of Financial Services and the Definition of Banking Markets for Antitrust Analysis, 37 THE ANTITRust BULLETIN (Fall 1992).

${ }^{9}$ Gregory E. Elliehausen and John D. Wolken, Banking Markets and the Use of Financial Services by Households, 78 Federal Reserve Bulletin (March 1992).

${ }^{10}$ The 1993 National Survey of Small Business Finances was co-sponsored by the 
their assets, liabilities, demographic characteristics, and use of financial services. The 1993 NSSBF interviewed 5,356 small businesses about their use of credit and other financial services. ${ }^{11}$ The data sets are uniquely well-suited to examining markets for financial services. In both surveys, respondents provide information about the institutions at which they have accounts or loans, including the institution type and its distance from the main office of the business (for the NSSBF) or from the home or workplace of the person who uses it most (for the SCF). These data permit an examination of the roles of institution type and location in the use of financial services.

For purposes of this study, institutions are divided into depository and nondepository institutions. Depositories include commercial banks, savings and loans (including savings banks), and credit unions. Nondepositories include finance companies, brokerage firms and mutual funds, leasing companies, and other institutions. ${ }^{12}$ For the NSSBF, nonfinancial institutions and unclassified sources are also shown separately. In both surveys, respondents identify their primary institution.

Because our interest is in markets for financial services typically supplied by banks, the analysis focuses on certain financial services. For households, the services covered are checking accounts, savings accounts, money market accounts (both money market deposit accounts and money market mutual funds), certificates of deposit, IRA and Keogh accounts, brokerage accounts, trusts and other managed assets, mortgages and

Small Business Administration. For general descriptions of the surveys, see Arthur B. Kennickell and Martha Starr-McCluer, Changes in Family Finances, 1989-1992: Evidence from the Survey of Consumer Finances, FEDERAL RESERVE BuLletin, 80 (October 1994) and Rebel A. Cole and John D. Wolken, Financial Services Used by Small Businesses: Evidence from the 1993 National Survey of Small Business Finances, FEDERAL Reserve BuLlETIN, 81 (July 1995). All data presented in this paper use the weights developed for each survey to adjust for sample design and nonresponse.

${ }^{11}$ Small businesses are defined as firms with fewer than 500 employees.

${ }^{12}$ Leasing companies are not reported separately for households. In the SCF, the main institutions in the "other" category are life insurance and mortgage companies. 
home equity loans, motor vehicle loans, home equity and other lines of credit, and other loans. ${ }^{13}$ For small businesses, the services covered are checking accounts, savings accounts, lines of credit, leases, mortgages, equipment loans, motor vehicle loans, other loans, and five financial management services (transaction, cash management, creditrelated, pension, and brokerage).

\section{Depository vs. Nondepository Institutions}

Table 1 shows the percentage of households (panel A) and the percentage of small businesses (panel B) using various types of depository and nondepository institutions. Looking at column 1 in both panels, almost 99 percent of both households and small businesses using financial services have at least one account at a depository institution. In contrast, only 35.7 percent of households, and 34.9 percent of small businesses use a nondepository institution. Nonetheless, the percentage of both groups using nondepositories is substantial, and consistent with the view that nondepositories should be taken seriously in competitive analysis.

The data in the rest of column 1 provide a deeper look at this segment of the market for financial services. The data show that commercial banks are by far the financial institution used most frequently by both households and small businesses. More importantly, some 96.5 percent of households, and 93.5 percent of small businesses say that a depository institution is their primary financial institution (column 2); only about four percent of both groups call a nondepository their primary institution. To an overwhelming extent, commercial banks are also the institution most frequently designated as the primary institution. Thus, the data suggest that, overall, depositories are

13 "Other" loans include consumer loans, home improvement loans, and education loans. The analysis excludes services not traditionally provided by banks, like life insurance and non money market mutual funds. The one service of potential interest that we are not able to cover is credit cards. The SCF collects limited information on institutions used for credit cards only. 
substantially more important for both households and small business than are nondepositories, although nondepositories are clearly relevant. In addition, commercial banks are, by a wide margin, the most important depository. ${ }^{14}$

V. Local vs. Nonlocal Institutions

Columns 4 and 5 of table 1 and tables 2 and 3 use a variety of measures to examine the importance of local financial institutions. ${ }^{15}$ With respect to depositories, table 1 shows that 97.5 percent of households, and 92.4 percent of small businesses, use a local depository institution. In stark contrast, only 20.2 percent of households, and not quite eight percent of small businesses use nonlocal depositories. The dominance of local institutions persists across commercial banks, savings institutions, and credit unions. However, the dominance of local institutions disappears for both households and small businesses with respect to their use of nondepositories. Indeed, the percentages of local and nonlocal use are very similar (compare columns 4 and 5) for all nondepository institutions. In short, the dominance of local institutions appears to be a characteristic of

\footnotetext{
${ }^{14}$ A paper by Rebel A. Cole, John D. Wolken, and R. Louise Woodburn, Bank and Nonbank Competition for Small Business Credit: Evidence from the 1987 and 1993 National Surveys of Small Business Finances, 82 FEdERAL Reserve Bulletin (November 1996), compares bank and nonbank credit use by small businesses using the 1987 and 1993 NSSBFs. This study examines both the incidence and the dollar shares of small business loans provided by various types of service providers. Interestingly, while the share of businesses using nonbanks remained constant, the share using banks declined from 1987 to 1993 . However, the dollar shares of small business credit outstanding provided by banks and nonbanks were essentially unchanged across the survey dates.

${ }^{15}$ For households, local institutions are defined as institutions (including ATMs) located within 30 miles of the home or workplace of the household member who uses it the most. Distances are coded up to a maximum of 50 miles, with greater distances recorded as "more than 50 miles." In the NSSBF, an institution is local if it is located within 30 miles of the headquarters office of the small business. Respondents are asked to report the number of miles between the firm and institution when the institution is located in the same city or metropolitan area. If the institution is located elsewhere, miles are calculated using institution and firm zipcode latitude and longitude.
} 
depositories, not nondepository institutions.

The role of local institutions is examined using the average number of financial services consumed at different types of institutions by households (panel A) and small businesses (panel B) in table 2. Focusing on column 4, it is clear that at depository institutions local institutions dominate by this measure as well. Overall, 90.7 percent of services consumed at depositories by households, and 94.6 percent of services consumed by small business are provided by local depositories. This result is robust across all three classes of depository institutions. In contrast, local nondepositories are important, but not nearly as critical as local depositories. For example, local institutions provide only 52.1 percent of services used at nondepositories by households, and 55.1 percent used by small businesses. Interestingly, within the class of nondepositories, local brokerage firms stand out as being particularly important for both households and small businesses. ${ }^{16}$

Our final measure of the role of local institutions considers the number of miles between users and their institutions. Specifically, for each institution where a household or small business purchased services, the distance between a household (small business) and the given institution is examined. ${ }^{17}$ Thus, a single household, or small business, has an observation for each institution where it reports that it conducts business. Table 3 displays the distribution of the distance in miles of these user-institution pairs across types of financial services. For households, financial services are divided into types of asset and credit services, and for small businesses services are separated into categories of asset, credit, and financial management services. Using the "checking" row of panel 3A as an example, the data indicate that households get 25 percent of their checking services at institutions within one mile of their home or work.

The results in table 3 generally reinforce the importance of local institutions, but also suggest a fairly complex story. For example, households obtain 75 percent of their

${ }^{16}$ It is also interesting to note that the data in column 1 of table 2 reinforce the results of section IV. On average, depository institutions, and especially commercial banks, provide substantially more services to both households and small businesses than do nondepositories.

${ }^{17}$ See footnote 12 for the precise definitions used. 
checking, savings, money market, certificate of deposit, and line of credit services at a financial institution within 10 miles of their home or workplace. Checking services stand out as dominated by local institutions; households purchase 90 percent of their checking services at an institution no more than 12 miles from their home or workplace. ${ }^{18}$ In addition, while local institutions are certainly important with respect to credit services for households, asset services generally appear to be more locally oriented than credit services. ${ }^{19}$

The differing degree of "localness" between asset and credit services for households is not as clear for small businesses. Indeed, small businesses seem more closely tied to local institutions across a wide range of services. For example, small businesses obtain 75 percent of their checking, savings, lines of credit, mortgage, other loans, transaction, cash management, and credit related services at a financial institution within 15 miles of their headquarters office. ${ }^{20}$ Still, asset services, here checking and

${ }^{18}$ An interesting implication of this result is that it suggests that geographically remote alternatives, such as money market funds, are generally not perfect substitutes for local transaction deposits. This supposition is supported by other data in the 1992 SCF which indicate that less than six percent of households had a money market fund. Even more telling, 98 percent of households with money market funds also had a checking or money market deposit account.

${ }^{19}$ This conclusion is supported by data (not shown) from the SCF regarding households' use of credit cards. Because the SCF does not collect distance information for institutions used for credit cards only, credit cards are not included in the analysis. However, the information that is available suggests that credit cards are among the less locally oriented financial services. Almost 58 percent of all general-purpose credit cards (e.g., Visa and MasterCard) held by households are issued by institutions where the household obtains no other financial service. It seems reasonable to presume that many of these institutions are not local firms.

${ }^{20}$ Transaction services include the provision of currency and coin, the processing of credit card receipts, the collection of night deposits, and wire transfers. Cash management services include the provision of sweep accounts, zero-balance accounts, and lockbox services. Credit-related services include bankers' acceptances, letters of credit, and factoring. 
savings services, stand out as dominated by local providers, while leases are clearly the service least likely to be local. ${ }^{21}$

\section{Clustering of Financial Services}

Of the issues examined in this study, the degree of clustering of financial services by households and small businesses is the most difficult to address empirically. The approach adopted here is to focus on the use of financial services at the institution identified by a survey respondent as their primary financial institution. Thus, our underlying assumption is that households and small businesses would be most likely to cluster at the institution where they conduct the majority, or at least the most important aspect, of their business. Conversely, if respondents do not cluster at their primary institution, then it would seem unlikely that they would cluster at any other institution. A second aspect of our approach is also to consider the relative importance of a service to households and small businesses. Services consumed by relatively few agents are not considered likely candidates for the cluster.

Tables 4 and 5 present data on the average number of financial services used per household (panel A) and per small business (panel B) at primary and nonprimary institutions. In table 4, the data are arrayed by the same types of services used in table 3; in table 5 the rows of the table are arranged by the type of primary institution. Consider column 4 of panel 4A, which gives the percent of each service purchased at the primary institution, and column 5, which gives the percent of households using the service. These data suggest that the services most frequently clustered at the primary institution may include checking, savings and money market accounts, lines of credit, and possibly certificates of deposit. Interestingly, these are precisely the same services most likely to be purchased locally (table 3 ). In addition, it is important to recall that primary

${ }^{21}$ The "local" importance of checking and savings services is reinforced by the high degree of localness exhibited by transaction and cash management services, both of which are closely related to deposit account activity. 
institutions are overwhelmingly depository institutions. Indeed, data not shown indicate that for 93 percent of households the primary institution is a local depository institution. In combination, these facts suggest that households often tend to cluster their purchases of certain financial services, and particularly asset services, at a local depository institution.

Comparable analysis of the data in columns 4 and 5 of panel 4B suggests that the services most frequently clustered at the primary institution by small businesses may be checking, savings, lines of credit, mortgages, transaction, cash management, and credit related services. As was the case for households, these are exactly the same services that are most likely to be purchased locally, and a small business' primary institution is almost certain to be a depository institution. Data not shown indicate that for 88 percent of small businesses the primary institution is a local depository institution. Thus, a strong circumstantial case can be made that small businesses, as well as households, frequently tend to cluster their purchases of certain financial services at a local depository institution. Unlike households, the cluster for small businesses appears to include not only asset services, but also important credit and financial management services.

Table 5 focuses on households' and small businesses' purchases of any services at their primary institutions. Concentrating first on columns 4 and 5 of panel $5 \mathrm{~A}$, it can be seen that when a household's primary institution is a depository institution, it is likely that at least 50 percent of all the financial services purchased by the household come from the primary institution. But such is not the case when a household's primary institution is a nondepository institution. For nondepositories, only about a third of the household's financial services tend to be purchased from the primary institution, and even then the percent of households purchasing more than one service from the primary institution tends to be 30 percent or lower (with the notable exception of purchases from brokerage firms). ${ }^{22}$ Taken together, these data support the view that there is some tendency for households to cluster their use of financial services at their local primary depository

\footnotetext{
${ }^{22}$ However, recall that only one percent of households claim that a brokerage firm is their primary institution (table 1, panel 1A, column 2). In contrast, almost 97 percent of households say a depository institution is their primary institution.
} 
institution, and to be considerably less likely to cluster on those relatively uncommon occasions when their primary institution is a nondepository.

Similar conclusions hold for small businesses. Indeed, small businesses appear somewhat more tied to depositories than are households. When a small business' primary institution is a depository, the small business purchases over 60 percent of its financial services at the primary institution. When the primary institution is not a depository, only a third or less of the small business' financial services are purchased at the primary nondepository. In addition, the percent of small businesses purchasing more than one service from the nondepository primary institution tends to be well below 30 percent (again, with the notable exception of purchases from brokerage firms). ${ }^{23}$

While this discussion provides some support for the notion of clustering by both households and small businesses, it is important not to overestimate the extent of this support. For example, the data in column 2 of panel 5A indicate that households purchase, on average, only slightly over two financial services at their primary depository institution. While this equals the average number of services purchased at all nonprimary institutions, it still suggests that there are only a small number of items in the average household's "cluster." Similar patterns are observed in the small business data (column 2, panel 5B), except that the mean number of services purchased at a small business' primary depository institution, while still only about two, is consistently greater than the mean number of services purchased at all nonprimary institutions. This is consistent with the view that clustering may be a more important concept for small businesses than for households.

\section{A Comment on Interpretation}

A problem with interpreting these data is that, while they represent equilibrium

${ }^{23}$ As was also true of households, recall that only one percent of small businesses claimed a brokerage firm as their primary institution (table 1, panel 1B, column 2), while almost 94 percent say a depository is their primary institution. 
conditions given the current market environment, they do not necessarily indicate how households and small businesses would behave if, say, local market prices increased substantially. The evidence presented here suggests that households and small businesses may well resist moving to a nonlocal institution for some services (but not others) because of increases in explicit prices alone. That is, the data are consistent with the view that, at least for some financial services, and at current prices, the transactions and information costs of using nonlocal providers dominate the benefits of going outside the local market area.

The survey data provide some direct evidence on the role of geographic proximity in the use of financial services. With respect to households, when asked to give their most important reason for choosing their main checking account institution, 44 percent of households listed "location," and 32 percent cited "many services in one place, already do business there." For checking services, only 14 percent of households gave "favorable interest rate and/or low fees" as the most important reason for choosing their main checking institution. ${ }^{24}$ In contrast, when asked the same question regarding their choice of primary mortgage institution, 27 percent of households indicated "favorable interest rate and/or low fees." Only 4 percent of households gave "location," and 17 percent cited "many services in one place, already do business there." 25

Results are similar for small businesses. When asked about factors which influenced the firm to use its primary institution, 37 percent of respondents indicated

${ }^{24}$ A recent study by Booz-Allen and Hamilton, InC., Consumer Demand For INTERnET BANKING, FINANCIAL SERVICES Group, New York (July 1996) cites an October 1995 American Bankers Association - Gallup poll regarding the most important reason that a consumer maintains an account with a financial institution. The single most important reason by far was "convenience," which was cited by almost 40 percent of respondents. "Friendly/Good Service" came in second at almost 20 percent; "long-standing relationship" was third, with almost 15 percent; and "checking held there" and "good interest rates" were virtually tied for fourth and fifth with about 11 percent each.

${ }^{25}$ Other important reasons cited for the choice of primary mortgage institution were "recommended" (25 percent), "easy to qualify" (13 percent), and "assumption by or financed through developer" (12 percent). 
location, 27 percent cited "many services in one place or already do business there," but only 6 percent identified "favorable interest rates or prices." Lastly, the importance of "many services in one place, already do business there" for both households' and small businesses' choice of their main checking account or primary institution suggests the clustering of some financial services by both groups.

VIII. Conclusion

This paper has investigated three of the most important issues that arise when analyzing the potential competitive effects of bank mergers on households and small businesses: (1) the relative importance of depository and nondepository institutions, (2) the extent to which markets for some financial services are geographically local, and (3) whether some financial services are clustered at an agent's primary financial institution. With respect to the first issue, our results suggest that, while nondepositories are clearly relevant, depository institutions are substantially more important for both households and small businesses. In addition, commercial banks are by a wide margin the most important depository.

For several important financial services, local firms are by far the dominant provider. For households, checking services stand out as overwhelmingly supplied by local firms. But other common products -- savings and money market deposits, CDs, and line of credit services -- are also in large part locally limited. In general, households appear to be more closely tied to local providers of asset services than they are to local providers of credit services, and the importance of local institutions is more a characteristic of depository institutions than it is of nondepositories.

Important financial services consumed by small businesses also have a strong tendency to be provided by local institutions. Indeed, small businesses may be more closely tied to local firms than are households. Checking and savings services stand out as dominated by local providers. Other important locally supplied services include lines of credit, mortgages, other loans, transaction, cash management, and credit related services. Overall, key asset and credit services consumed by small businesses are 
provided primarily by local institutions, and, as with households, the importance of local institutions is more a characteristic of depositories than of nondepositories.

This study provides some support for the argument that substantial proportions of households and small businesses cluster their purchases of a few key financial services at their local primary depository institution. For households, these services appear to be the same asset services that are locally limited. For small businesses, clustered services appear to be the same asset and credit services that are locally limited. Finally, the data suggest that, for both households and small businesses, clustering is mostly a characteristic of the purchase of services at their local primary depository institution, and considerably less likely to occur on those relatively uncommon occasions when their primary institution is a nondepository.

These results are, on balance, consistent with previous studies and supportive of the methodology currently used at the Federal Reserve and the Department of Justice for analyzing the potential competitive effects of bank mergers. Overall, they suggest that, for perhaps the vast majority of households and small businesses, use of financial services has not changed as much in recent years as some observers have argued. However, it is also clear that further research would be very useful. One interesting extension of the current work would be to investigate households' and small businesses' use of financial services as a function of agent and market characteristics. The authors are currently pursuing such an effort. Another important topic is the dynamics of household and small business responses to changes in the explicit and implicit prices of financial services. Our final suggestion concerns the impact of electronic banking on the importance of potential competition in banking. ${ }^{26}$ Studies of the nature of household and small business use and acceptance of various electronic media for financial services would be quite useful,

${ }^{26}$ There is a small, and hopefully growing literature in this area. See, for example, Rhoades, op. cit. and ARthur B. Kennickell and Myron L. KWAst, Who Uses Electronic Banking? Preliminary Results from the I 995 SurVey of CONSUMER FINANCES, presented at the Annual Meetings of the Financial Management Association (October 1996), Board of Governors of the Federal Reserve System, Washington, D.C. 
especially in better understanding the possible future course of defining banking markets. 


\section{Table 1}

Panel 1A: Percent of Households Using Various Types of Institution

By type of institution and selected institution characteristic

\begin{tabular}{l|c|c|c|c|c}
\hline \multirow{2}{*}{$\quad$} & $(1)$ & $(2)$ & $(3)$ & $(4)$ & \multicolumn{2}{c}{$(5)$} \\
\cline { 2 - 6 } \multicolumn{1}{c}{ Type of institution } & \multirow{3}{*}{ All } & \multicolumn{3}{|c|}{ Institution characteristic } \\
\cline { 2 - 6 } All & $\mathbf{1 0 0}$ & $\mathbf{1 0 0}$ & $\mathbf{7 2 . 0}$ & $\mathbf{9 8 . 3}$ & $\mathbf{3 5 . 7}$ \\
Depository & 98.9 & 96.5 & 62.9 & 97.5 & 20.2 \\
Commercial bank & 83.3 & 71.3 & 40.9 & 80.6 & 11.3 \\
Savings & 29.5 & 13.4 & 19.7 & 26.5 & 4.3 \\
Credit union & 31.8 & 11.8 & 22.2 & 26.8 & 6.6 \\
Nondepository & 35.7 & 3.5 & 33.3 & 20.3 & 20.7 \\
Finance company & 13.1 & 1.7 & 11.8 & 6.2 & 7.8 \\
Brokerage firm & 16.3 & 1.0 & 15.7 & 10.7 & 7.3 \\
Other & 12.2 & .8 & 11.4 & 4.6 & 7.8 \\
\hline
\end{tabular}

Note: Excludes households that do not use financial services provided by an institutional source.

Source: 1992 Survey of Consumer Finances.

Panel 1B: Percent of Small Businesses Using Various Types of Institution

By type of financial institution and selected institution characteristic

\begin{tabular}{|c|c|c|c|c|c|}
\hline \multirow[b]{3}{*}{ Type of institution } & (1) & (2) & (3) & (4) & (5) \\
\hline & \multirow[b]{2}{*}{ All } & \multicolumn{4}{|c|}{ Institution characteristic } \\
\hline & & Primary & Nonprimary & Local $(\leq 30$ miles $)$ & Nonlocal (> 30 miles) \\
\hline All & 100 & 98.5 & 54.0 & 93.3 & 16.9 \\
\hline Depository & 98.7 & 93.5 & 35.5 & 92.4 & 7.6 \\
\hline Commercial bank & 91.4 & 83.9 & 30.2 & 84.9 & 6.4 \\
\hline Savings & 12.1 & 7.7 & 5.1 & 10.9 & .8 \\
\hline Credit union & 4.4 & 1.9 & 2.5 & 3.6 & .4 \\
\hline Nondepository & 34.9 & 4.3 & 32.8 & 13.5 & 10.8 \\
\hline Finance company & 13.4 & 1.4 & 12.4 & 3.8 & 4.1 \\
\hline Brokerage firm & 9.9 & 1.0 & 9.1 & 5.9 & 2.3 \\
\hline Leasing & 8.0 & .5 & 7.6 & 2.4 & 3.0 \\
\hline Other ND financial & 3.7 & .2 & 3.5 & 1.1 & .8 \\
\hline Nonfinancial & 8.7 & 1.1 & 8.0 & 1.4 & 1.4 \\
\hline
\end{tabular}

Note: Excludes small businesses that do not use financial services provided by an institutional source.

Source: 1993 National Survey of Small Business Finances. 


\section{Table 2}

Panel 2A: Average Number of Financial Services Used Per Household at Local and Nonlocal Institutions By type of institution

\begin{tabular}{|c|c|c|c|c|}
\hline & (1) & (2) & (3) & (4) \\
\hline Type of institution & All & Local ( $\leq 30$ miles $)$ & Nonlocal (> 30 miles) & $\begin{array}{l}\text { Memo: } \\
\text { Services at local institutions } \\
\text { as a percent of all services }\end{array}$ \\
\hline All & 4.24 & 3.58 & .66 & 84.4 \\
\hline Depository & 3.53 & 3.20 & .32 & 90.7 \\
\hline Commercial bank & 2.23 & 2.07 & .16 & 92.8 \\
\hline Savings & .63 & .57 & .06 & 90.5 \\
\hline Credit union & .67 & .57 & .10 & 85.1 \\
\hline Nondepository & .71 & .37 & .34 & 52.1 \\
\hline Finance company & .18 & .08 & .10 & 44.4 \\
\hline Brokerage firm & .37 & .23 & .14 & 62.2 \\
\hline Other & .16 & .06 & .10 & 37.5 \\
\hline
\end{tabular}

Source: 1992 Survey of Consumer Finances.

Panel 2B: Average Number of Financial Services Used Per Small Business at Local and Nonlocal Institutions By type of institution

\begin{tabular}{|c|c|c|c|c|}
\hline & (1) & (2) & (3) & (4) \\
\hline Type of institution & All & Local $(\leq 30$ miles $)$ & Nonlocal (> 30 miles) & $\begin{array}{l}\text { Memo: } \\
\text { Services at local institutions } \\
\text { as a percent of all services }\end{array}$ \\
\hline All & 3.11 & 2.78 & .32 & 89.4 \\
\hline Depository & 2.45 & 2.32 & .13 & 94.6 \\
\hline Commercial bank & 2.19 & 2.07 & .12 & 94.7 \\
\hline Savings & .20 & .19 & .01 & 95.2 \\
\hline Credit union & .07 & .06 & .01 & 90.3 \\
\hline Nondepository & .61 & .34 & .24 & 55.1 \\
\hline ND financial & .48 & .27 & .19 & 56.1 \\
\hline Finance company & .18 & .08 & .09 & 46.0 \\
\hline Brokerage firm & .15 & .11 & .04 & 73.8 \\
\hline Leasing & .11 & .04 & .06 & 39.0 \\
\hline Other & .04 & .02 & .02 & 55.0 \\
\hline Nonfinancial & .13 & .06 & .04 & 47.0 \\
\hline Source unknown & .04 & .04 & .00 & 88.9 \\
\hline
\end{tabular}

Note: The data for the local/nonlocal distribution of nondepository sources should be regarded as preliminary.

Source: 1993 National Survey of Small Business Finances. 
Table 3

Panel 3A: Number of Miles Between Households and Their Institutions

By type of financial service

\begin{tabular}{|c|c|c|c|c|}
\hline \multirow[b]{2}{*}{ Type of service } & \multicolumn{4}{|c|}{ Distance in miles by percentile } \\
\hline & 25 th & Median & 75 th & 90th \\
\hline Asset & $<1$ & 3 & 8 & 50 \\
\hline Checking & $<1$ & 2 & 5 & 12 \\
\hline Savings & $<1$ & 3 & 8 & 50 \\
\hline Money market & $<1$ & 3 & 10 & 50 \\
\hline Certificate of deposit & $<1$ & 3 & 6 & 20 \\
\hline IRA orKeogh & 2 & 5 & 25 & 50 \\
\hline Brokerage & 4 & 10 & 50 & 50 \\
\hline Trust & 3 & 15 & 50 & 50 \\
\hline Credit & 2 & 7 & 50 & 50 \\
\hline Mortgage & 3 & 8 & 50 & 50 \\
\hline Motor vehicle & 2 & 7 & 22 & 50 \\
\hline Line of credit & $<1$ & 3 & 10 & 50 \\
\hline Other loan & 2 & 10 & 50 & 50 \\
\hline
\end{tabular}

Note: Distances are recorded up to a maximum of 50 miles.

Source: 1992 Survey of Consumer Finances.

Panel 3B: Number of Miles Between Small Businesses and Their Institutions

By type of financial service

\begin{tabular}{|c|c|c|c|c|}
\hline \multirow[b]{2}{*}{ Type of ervice } & \multicolumn{4}{|c|}{ Distance in miles by percentile } \\
\hline & 25 th & Median & 75th & 90th \\
\hline Asset & 1 & 2 & 5 & 15 \\
\hline Checking & 1 & 2 & 5 & 13 \\
\hline Savings & 1 & 2 & 6 & 17 \\
\hline Credit & 1 & 5 & 25 & 264 \\
\hline Lines of credit & 1 & 4 & 11 & 45 \\
\hline Leases & 5 & 39 & 431 & 1,214 \\
\hline Mortgage loan & 1 & 4 & 12 & 35 \\
\hline Equipment loan & 1 & 5 & 35 & 494 \\
\hline Motor vehicle loan & 2 & 6 & 25 & 137 \\
\hline Other loan & 1 & 4 & 12 & 139 \\
\hline Financial management services & 1 & 3 & 10 & 55 \\
\hline Transaction & 1 & 2 & 5 & 20 \\
\hline Cash management & 1 & 3 & 10 & 30 \\
\hline Credit related & 1 & 3 & 14 & 74 \\
\hline Pension & 3 & 7 & 21 & 250 \\
\hline Brokerage & 3 & 7 & 24 & 216 \\
\hline
\end{tabular}

Source: 1993 National Survey of Small Business Finances. 


\section{Table 4}

Panel 4A: Average Number of Financial Services Used Per Household at Primary and Nonprimary Institutions

By type of financial service

\begin{tabular}{|c|c|c|c|c|c|}
\hline \multirow[b]{3}{*}{ Type of service } & (1) & (2) & (3) & (4) & (5) \\
\hline & \multirow[b]{2}{*}{ All institutions } & \multirow[b]{2}{*}{ Primary institution } & \multirow[b]{2}{*}{$\begin{array}{l}\text { All nonprimary } \\
\text { institutions }\end{array}$} & \multicolumn{2}{|c|}{ Memo } \\
\hline & & & & $\begin{array}{c}\text { Services at primary } \\
\text { institutions as percent } \\
\text { of all services }\end{array}$ & $\begin{array}{l}\text { Percent of } \\
\text { households using } \\
\text { the service }\end{array}$ \\
\hline \multirow{9}{*}{$\begin{array}{l}\text { All services } \\
\text { Asset } \\
\text { Checking } \\
\text { Savings } \\
\text { Money market } \\
\text { Certificate of deposit } \\
\text { IRA or Keogh } \\
\text { Brokerage } \\
\text { Trust }\end{array}$} & 4.24 & 2.11 & 2.13 & 49.8 & 100 \\
\hline & 3.13 & 1.72 & 1.41 & 55.0 & 96.9 \\
\hline & 1.16 & .86 & .30 & 74.1 & 85.7 \\
\hline & .80 & .42 & .38 & 52.5 & 48.8 \\
\hline & .34 & .17 & .16 & 51.3 & 23.2 \\
\hline & .25 & .11 & .13 & 46.3 & 18.4 \\
\hline & .43 & .13 & .29 & 31.1 & 25.6 \\
\hline & .12 & .01 & .11 & 11.6 & 10.1 \\
\hline & .04 & .01 & .03 & 16.2 & 3.2 \\
\hline \multirow{5}{*}{$\begin{array}{l}\text { Credit } \\
\text { Mortgage } \\
\text { Motor vehicle } \\
\text { Line of credit } \\
\text { Other loan }\end{array}$} & 1.12 & .39 & .73 & 34.6 & 59.7 \\
\hline & .49 & .16 & .33 & 32.6 & 39.5 \\
\hline & .29 & .10 & .19 & 34.4 & 25.2 \\
\hline & .15 & .07 & .07 & 49.5 & 12.2 \\
\hline & .19 & .06 & .14 & 29.1 & 13.7 \\
\hline
\end{tabular}

Source: 1992 Survey of Consumer Finances.

Panel 4B: Average Number of Financial Services Used Per Small Business at Primary and Nonprimary Institutions By type of financial service

\begin{tabular}{|c|c|c|c|c|c|}
\hline \multirow[b]{3}{*}{ Type of service } & (1) & (2) & (3) & (4) & (5) \\
\hline & \multirow[b]{2}{*}{ All institutions } & \multirow[b]{2}{*}{ Primary institution } & \multirow[b]{2}{*}{$\begin{array}{l}\text { All nonprimary } \\
\text { institutions }\end{array}$} & \multicolumn{2}{|c|}{ Memo } \\
\hline & & & & $\begin{array}{c}\text { Services at primary } \\
\text { institutions as percent } \\
\text { of all services }\end{array}$ & $\begin{array}{l}\text { Percent of small } \\
\text { businesses using } \\
\text { financial service }\end{array}$ \\
\hline \multirow{4}{*}{$\begin{array}{l}\text { All services } \\
\text { Asset } \\
\text { Checking } \\
\text { Savings }\end{array}$} & 3.10 & 1.86 & 1.24 & 59.9 & 100 \\
\hline & 1.46 & 1.10 & .36 & 75.2 & 99.2 \\
\hline & 1.16 & .91 & .25 & 78.8 & 98.7 \\
\hline & .30 & .18 & .11 & 61.4 & 25.0 \\
\hline \multirow{7}{*}{$\begin{array}{l}\text { Credit } \\
\text { Lines of credit } \\
\text { Leases } \\
\text { Mortgage loan } \\
\text { Equipment loan } \\
\text { Motor vehicle loan }\end{array}$} & 1.07 & .46 & .61 & 42.9 & 55.1 \\
\hline & .34 & .22 & .12 & 64.2 & 26.3 \\
\hline & .13 & .01 & .11 & 11.3 & 9.4 \\
\hline & .07 & .03 & .03 & 51.4 & 6.1 \\
\hline & .17 & .07 & .10 & 41.3 & 13.9 \\
\hline & .29 & .09 & .20 & 30.1 & 24.5 \\
\hline & .08 & .04 & .04 & 46.4 & 6.7 \\
\hline \multirow{2}{*}{$\begin{array}{l}\text { Financial management services } \\
\text { Transaction }\end{array}$} & .58 & .31 & .27 & 52.8 & 36.4 \\
\hline & .29 & .19 & .10 & 65.1 & 23.9 \\
\hline \multirow{3}{*}{$\begin{array}{l}\text { Cash management } \\
\text { Credit related } \\
\text { Pension }\end{array}$} & .06 & .05 & .01 & 77.5 & 5.4 \\
\hline & .06 & .04 & .02 & 61.4 & 4.7 \\
\hline & .11 & .03 & .09 & 22.4 & 4.4 \\
\hline Brokerage & .05 & .01 & .05 & 13.4 & 10.1 \\
\hline
\end{tabular}

Source: 1993 National Survey of Small Business Finances. 


\section{Table 5}

Panel 5A: Average Number of Financial Services Used Per Household at Primary and Nonprimary Institutions By type of primary institution

\begin{tabular}{|c|c|c|c|c|c|}
\hline \multirow[b]{3}{*}{ Type of primary institution } & (1) & (2) & (3) & (4) & (5) \\
\hline & \multirow[b]{2}{*}{ Total } & \multirow[b]{2}{*}{ Primary institution } & \multirow[b]{2}{*}{$\begin{array}{c}\text { All nonprimary } \\
\text { institutions }\end{array}$} & \multicolumn{2}{|c|}{ Memo } \\
\hline & & & & $\begin{array}{l}\text { Services at primary } \\
\text { institutions as a } \\
\text { percent of all } \\
\text { services }\end{array}$ & $\begin{array}{l}\text { Percent of } \\
\text { households using } \\
\text { more than one } \\
\text { service at primary } \\
\text { institution }\end{array}$ \\
\hline All & 4.24 & 2.11 & 2.13 & 49.8 & 56.4 \\
\hline Depository & 4.24 & 2.13 & 2.11 & 50.2 & 57.3 \\
\hline Commercial bank & 4.18 & 2.07 & 2.11 & 49.5 & 54.7 \\
\hline Savings & 4.15 & 2.15 & 2.00 & 51.8 & 57.4 \\
\hline Credit union & 4.69 & 2.49 & 2.20 & 53.1 & 72.9 \\
\hline Nondepository & 4.21 & 1.51 & 2.70 & 35.9 & 30.4 \\
\hline Finance company & 3.50 & 1.38 & 2.12 & 39.4 & 17.3 \\
\hline Brokerage firm & 6.30 & 2.06 & 4.24 & 32.7 & 68.2 \\
\hline Other & 3.11 & 1.11 & 2.00 & 35.7 & 11.1 \\
\hline
\end{tabular}

Source: 1992 Survey of Consumer Finances.

Panel 5B: Average Number of Financial Services Used Per Small Business at Primary and Nonprimary Institutions By type of primary financial institution

\begin{tabular}{|c|c|c|c|c|c|}
\hline \multirow[b]{3}{*}{ Type of primary institution } & (1) & (2) & (3) & (4) & (5) \\
\hline & \multirow[b]{2}{*}{ Total } & \multirow[b]{2}{*}{ Primary institution } & \multirow[b]{2}{*}{$\begin{array}{c}\text { All nonprimary } \\
\text { institutions }\end{array}$} & \multicolumn{2}{|c|}{ Memo } \\
\hline & & & & $\begin{array}{l}\text { Services at primary } \\
\text { institutions as a } \\
\text { percent of all } \\
\text { services }\end{array}$ & $\begin{array}{c}\text { Percent of } \\
\text { businesses using } \\
\text { more than one } \\
\text { service at primary } \\
\text { institution }\end{array}$ \\
\hline All & 3.10 & 1.86 & 1.24 & 59.9 & 53.2 \\
\hline Depository & 3.07 & 1.92 & 1.16 & 62.4 & 54.6 \\
\hline Commercial bank. & 3.10 & 1.94 & 1.16 & 62.5 & 55.4 \\
\hline Savings & 2.73 & 1.68 & 1.05 & 61.6 & 47.0 \\
\hline Credit union & 3.05 & 1.78 & 1.27 & 58.4 & 51.9 \\
\hline Nondepository & 4.29 & 1.36 & 2.93 & 31.8 & 26.1 \\
\hline ND financial & 4.35 & 1.44 & 2.91 & 33.2 & 30.6 \\
\hline Finance company & 4.66 & 1.32 & 3.34 & 28.3 & 22.5 \\
\hline Brokerage & 4.27 & 1.87 & 2.40 & 43.8 & 57.0 \\
\hline Leasing & 4.11 & 1.08 & 3.03 & 26.2 & 7.8 \\
\hline Other & 3.16 & 1.19 & 1.96 & 37.8 & 19.4 \\
\hline Nonfinancial & 4.13 & 1.14 & 2.98 & 27.7 & 13.7 \\
\hline Source unknown & 4.11 & 1.08 & 3.03 & 26.2 & 26.3 \\
\hline
\end{tabular}

Source: 1993 National Survey of Small Business Finances. 